\title{
Correction to: Enhancing the Relevance and Effectiveness of a Youth Gambling Prevention Program for Urban, Minority Youth: A Pilot Study of Maryland Smart Choices
}

\author{
Brittany R. Parham ${ }^{1}$ D . Carl Robertson ${ }^{2}$. Nancy Lever ${ }^{1}$. Sharon Hoover ${ }^{1}$. \\ Tracy Palmer ${ }^{3} \cdot$ Phyllis Lee $^{4} \cdot$ Kelly Willis $^{1} \cdot$ Joanna Prout ${ }^{1}$ \\ Published online: 24 September 2018 \\ (c) Springer Science+Business Media, LLC, part of Springer Nature 2018
}

\section{Correction to: Journal of Gambling Studies https://doi.org/10.1007/s10899-018-9797-4}

The article Enhancing the Relevance and Effectiveness of a Youth Gambling Prevention Program for Urban, Minority Youth: A Pilot Study of Maryland Smart Choices, written by Brittany R. Parham, Carl Robertson, Nancy Lever, Sharon Hoover, Tracy Palmer, Phyllis Lee, Kelly Willis and Joanna Prout, was originally published electronically on the publisher's internet portal (currently SpringerLink) on 18 August 2018 with open access. With the author(s)' decision to step back from Open Choice, the copyright of the article changed on 10 September 2018 to (C) Springer Science+Business Media, LLC, part of Springer Nature 2018 and the article is forthwith distributed under the terms of copyright.

The original article has been corrected.

The original article can be found online at https://oi.org/10.1007/s10899-018-9797-4.

Brittany R. Parham

bparham@som.umaryland.edu

1 Center for School Mental Health, University of Maryland School of Medicine, 737 West Lombard, Street (4th Floor), Baltimore, MD 21201, USA

2 The Maryland Center of Excellence on Problem Gambling, University of Maryland School of Medicine, 5900 Waterloo Road, Suite 200, Columbia, MD 20145, USA

3 Department of Psychology, Northern Virginia Community College, 8333 Little River Turnpike, Annandale, VA 22003, USA

4 Department of Psychological Science, Eastern Connecticut State University, 83 Windham Street, Willimantic, CT 06226, USA 